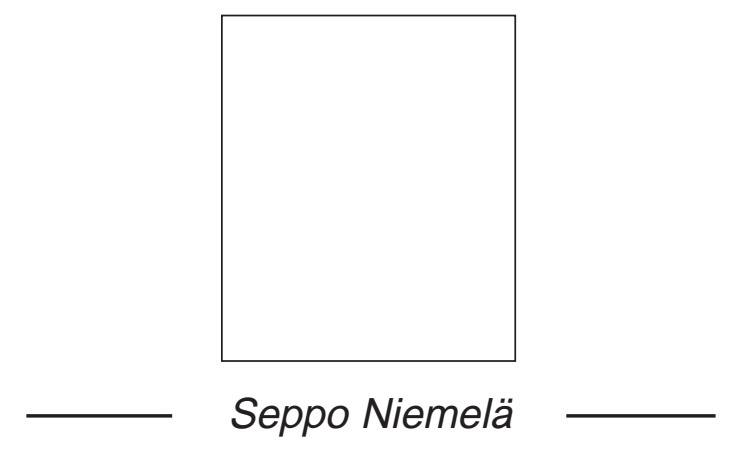

\title{
Vapaan sivistystyön kolme tehtävää
}

\author{
Perimmältään vasta sivistys tekee ihmisestä ihmisen. Seuraavassa \\ artikkelissa tarkastellaan vapaan sivistystyön ydintehtäviä \\ nykyajassa. Mitä on persoonallisuuden kehitys ja itse sivistys? \\ Mitä toiminta yhteisöissä ja viimekädessä kansalaisyhteiskunnassa \\ on? Ja mitä on yhteiskunnallinen tai kansanvaltakasvatus tänään? \\ Entä mikä on päätöksentekijäin suhde kuvattuihin \\ sivistystehtäviin?
}

\begin{abstract}
Vapaa sivistystyö on pohjoismainen ilmiö, vaikkakin sen tehtävät on tavalla tai toisella järjestetty kaikissa yhteiskunnissa. Silti sivistystyö on myös Pohjoismaissa etsinyt toisistaan poikkeavat muodot. Kansanopistoliike on kaikissa maissa vahva. Muutoin Ruotsi, Tanska ja Norjakin perustavat toiminnan opintoliittoihin ja niiden taustana oleviin kansanliikkeisiin, kun taas Suomi on kunnallispainotteinen. Kun moni vapaan sivistystyön oppilaitos tosiasiassa paikkaa koululaitoksen tehtäviä, on aidosti arvoperustainen vapaa sivistystyö Suomessa vähäistä. Lisäksi se kärsi lamaleikkauksissa enemmän kuin juustohöylä olisi edellyttänyt, mikä opetushallinnon osalta oli tietoista rakennepolitiikkaa. Vapaan sivistystyön tuloksiin oltiin tyytymättömiä ja sen kyky perustella olemassaoloaan oli heikko. Toimialan kannalta on ongelma, että alaan kohdistuva tutkimustyö on pitkään ollut vähäinen. K aikki tämä johti siihen, että vapaa sivistystyö oli menettää omaleimaisuutensa ja ehkä olemassaolonsakin osana koulutusta koskevan lainsäädännön kokonaisuutta. (K s. viite 1 sivulla 226 )
\end{abstract}

Vuosikymmenen loppu on kuitenkin tuonut alavireiseen kuvaan odotuksen vapaan sivistystyön uudesta tulemisesta. Tärkeintä on, että monissa alan oppilaitoksissa on käynnissä kiinnostava kehitystyö, jossa vapaa sivistystyö hakee paikkaansa tietoyhteiskunnassa. V altion tuki antaa sille enää lähtökohdan. Voimavaroja on etsittävä EU:n myötä ja muutoinkin kasvaneesta hanketoiminnasta. K ehityshankkeet ovat toisaalta mahdollisuus, mutta toisaalta ne sitovat vähät voimat anomusten ja raporttien oravanpyörään.

M erkittävä julkinen tahdonilmaus on keväällä säädetty laki vapaasta sivistystyöstä. Se määrittää valtion suhteen kansanopistojen, kansalais- ja työväenopistojen ja opintokeskusten lisäksi liikunnan oppilaitoksiin ja kesäyliopistoihin. Lain tarkoituspykälä juurtuu pohjoismaisen kansansivistyksen pitkään perinteeseen, mutta tarjoaa samalla ponnistuspohjan 2000 luvulle. Sen mukaiset vapaan sivistystyön tehtävät liittyvät elinikäisen oppimisen periaatteen pohjalta persoonallisuuden monipuoliseen 
kehittämiseen ja yhteisöissä toimimiseen. Annettuina arvoina ovat kansanvalta, tasaarvoisuus ja moniarvoisuus; jälkimmäinen kannustaa kutakin oppilaitosta toimimaan omien arvojensa pohjalta, mikä vahvistaa moniarvoista yhteiskuntaa.

Vapaan sivistystyön kevään merkkeihin kuuluu opetushallinnon asenne, jonka voi sanoa muuttuneen varauksellisen epäilevästä myönteisen odottavaksi. Esimerkiksi opetusministeriön aikuiskoulutuspoliittisen yksikön johtaja $\mathrm{Ma}$ rita Savolan (1997, 15) henkilökohtainen aikuiskoulutuspoliittinen visio 2000-luvulle sisältää "eräänlaisen vapaan sivistystyön uuden tulemisen".

\section{Elämänpitkä oppiminen}

Laki antaa vapaan sivistystyön toimintaperiaatteeksi elinikäisen oppimisen. A atehistoriallisesti se jatkaa sivistystyön itsekasvatusperinnettä. A jatus elinikäisestä oppimisesta näyttää muutoinkin pitkän koulutuspainotteisen kauden jälkeen tukevan vapaan sivistystyön perusajatuksia. Elinikäisen oppimisen analyysit - myös sellaisina kuin OECD tai EU:kin niitä tekevät ovat sivistysperinteen kannalta kiinnostavia.

H yvä esimerkki useista samaahakevista luetteloista esitettiin OECD:n seminaarissa Tukholmassa vuonna 1997. Sen mukaan elinikäisen oppimisen tavoitteita ovat persoonallisuuden kehitys (mukaanlukien työn ulkopuolinen aika ja eläkeikä), demokraattisten arvojen vahvistaminen, yhteisöllisen elämän viljeleminen, sosiaalisen koheesion ylläpitäminen ja vasta sitten innovatiivisuus, tuottavuus ja taloudellinen kasvu. Lähes sama tavoiteluettelo on E linikäisen oppimisen komitean mietinnössä $(1997,29)$. Listan alku on merkillepantavan yhtäläinen vapaan sivistystyön useimpien määritelmien ja myös uuden lain tarkoituspykälän kanssa. Tämän mukaan vapaat sivistystyöt eivät todellakaan ole tehdyt. E dessämme on yhdessä tietoyhteiskunnan ihmisen kanssa mitä mittavin sivistyshaaste.

Vapaalla sivistystyöllä on lisäksi mahdollisuus tulla yhdeksi muurinmurtajaksi kehityksessä, jossa ajoittaiskoulutuksen yhteiskunta muuttuu elämänpitkän oppimisen yhteiskunnaksi. K iinnostuksen kohteena ovat toisaalta se oppimisen perusta, jonka turvin inminen voi olla elinikäinen oppija ja toisaalta yhteisöt oppivina ja oppimista tukevina organisaatioina. Tältäkin kannalta persoonallisuuden kehitys tai perimmiltään itse sivistys on merkittävä asia, samoin useiden vapaan sivistystyön organisaatioiden kokemus toiminnasta kansalaisjärjestöjen oppimiskeskuksina.

Vapaan sivistystyön oppilaitokset voivat näyttää tietä muutoksessa, jossa koulutuksen järjestäjästä tulee oppimisen edistäjä ja yhteisöllisten oppimisprosessien ohjaaja "oppivan organisaation" ajatuksen mukaisesti. Myös komitea nosti ensimmäistä kertaa vuosikymmeniin kansalaisjärjestöissä oppimisen kehittämisen painopisteeksi (s. 52). K un elinikäisen oppimisen ajatusten mukaisesti opittu pitää tunnustaa, syntyy vapaan sivistystyön oppilaitoksille uusi haaste. Myös niiden ja kansalaistoiminnan piirissä opittu tarvitsee oman tunnustamisensa, jolle tulee etsiä alan traditioon sopivat muodot.

Vapaalla sivistystyöllä on kunniakas menneisyys. Sillä on myös aito mahdollisuus löytää paikkansa 2000-luvun jälkiteollisessa tietoyhteiskunnassa. Tarkastelen seuraavassa tietoyhteiskunnan murroksen taustaa vasten vapaan sivistystyön tehtävää ja arvioin sen merkitystä uuden lain tarkoituspykälän pohjalta. K ysyn, mitä persoonallisuuden kehitys tai itse sivistys on? M itä toiminta yhteisöissä ja viimekädessä kansalaisyhteiskunta on? Ja lopuksi tavallaan edellisen alakohtana sitä, mitä yhteiskunnallinen tai kansanvaltakasvatus on?

\section{PERSOONALLISUUDEN KEHITTÄMINEN}

E i ehkä ole asiatonta hakea persoonallisuuden kehittämisen lähtökohtia 2000-Iuvun tarpeisiin suomalaisuusliikkeen sivistyskäsityksestä, siksikään että se on niin voimakkaasti vaikuttanut 
Suomen henkiseen ja kansanelämään. O len tiivistänyt kirjassa 'Suomen ehdot' niin sanotusti 'jälkisnellmanilaisen' käsityksen ytimen seuraavaan tapaan (myös K uisma - N iemelä 1983, 205-). Perimmiltään sivistys on sitä, mikä tekee inmisestä inmisen. Ihmisessä tosin toimii luonnonperusta samoin kuin eläimessäkin, mutta hän ei ole siihen samalla tavoin sidottu ja voi kehittää henkisen kasvun avulla kulttuuriominaisuuksiaan. Sivistymisen elinikäistä prosessia voi lähestyä itsenäistymisen ja jäsentymisen osin sisäkkäisinä ja toisiaan täydentävinä prosesseina (esim. Wilenius ym, 1979, 34).

K lassisen filosofisen käsityksen mukaan inmisessä on kasvuun valmiina mahdollisuutena kolme henkistä aluetta. Tunnetuin on ryväs, johon eri tavoin viittaavat sanat tietäminen, ajattelu, käsitteellisyys, harkinta, tiede ja totuudellisuus. Toinen on tunteen, ilmaisun, taiteen ja esteettisyyden alue. K olmas sisältää tahdon, toiminnan, kätevyyden ja eettisyyden. $N$ äiden viriämisen mukana ihminen itsenäistyy; perinteen, muodin ja yleisen mielipiteen inmistä tiedottomasti ohjaava vaikutus heikkenee ja inminen voi tietoisemmin suunnata toimintaansa oman harkintansa varassa. Vanhastaan tätä nimitettiin itsetietoisuuden heräämiseksi; "kynnän oman vakoni elämänsarkaan". Tuloksena on inmisen omaperäisen ajattelu-, tuntemis- ja toimintakyvyn kehittyminen.

Ihminen rakentaa maailmankatsomuksensa muodostamalla omakohtaisen suhteen luontoon, ekologiaan ja miljööseen, lähiyhteisöihin, yhteiskuntaan ja globaalistuvaan maailmaan sekä arvoihin ja kulttuuriin. N yt-hetki avautuu menneeseen ja tulevaan. Takana on historia, myös luonnon- ja lajihistoria, tavat ja perinne. $E$ dessä on menneiden valintojen rajaama mutta monessa suhteessa avoin tulevaisuus. Sen muotoamiseksi inminen voi itse ja yhdessä toisten kanssa asettaa päämääriä. E lämänkatsomus tulkitsee inmisen tehtävän ja tavoitteet maailmassa. Niiden ydin kiteytyy vakaumukseksi. Se kertoo - kuten J. V. Snellman kauniisti sanoi - asiat, joiden puolesta olemme valmiit taistelemaan elämässä. Tämän perustan varassa inminen jäsentyy tai sosiaalistuu ympäristöönsä sen toimivaksi osaksi ja suuntaa toimintansa laajemman kokonaisuuden hyväksi.

\section{Henkinen kasvu ja valtautuminen}

Sivistystyö on kaiken edellä kuvatun tietoista viljelyä. (Viite 2). Henkisen kasvun tuloksena on monipuolisesti kehittynyt persoonallisuus, joka kykenee itsenäiseen toimintaan ryhmiensä, yhteisöjensä ja yhteiskuntansa jäsenenä. Sivistymisen perusta luodaan varhaiskasvatuksessa ja koulussa, mutta prosessi on sananmukaisesti elinikäinen, elämän koulu. Sen edistäminen oppimisen keinoin on vapaan sivistystyön perimmäinen tehtävä ja toteutuu aina, kun inmiset kokoontuvat pohtimaan omia tai yhteisiä asioita, harrastamaan taidetta ja muuta kulttuuria tai toimimaan tärkeäksi kokemiensa asioiden puolesta. Prosessi on laaja ja perimmältään avoin eikä sen kokonaisuutta tule puristaa ahtaiden määritelmien tai tavoitteiden rajoihin.

Silti eri aikakaudet nostavat esiin sivistyksen eri piirteitä. OECD korostaa persoonallisuuden kehitystä siksi, että se on mm. aloitekyvyn perusta. Aloitekyky onkin yhteistyökyvyn rinnalla yksi jälkiteollisen tietoyhteiskunnan tärkeimpiä ominaisuuksia nyt, kun jäykät, hierarkkiset ja koulutukseen perustuvat järjestelmät purkautuvat joustaviksi, vuorovaikutusta ja oppimista edellyttäviksi verkostoiksi.

K ehittämishankkeista saatu kotimainen ja eurooppalainenkin kokemus puhuu sen puolesta, että usein inmiset tarvitsevat ennen uuteen ryhtymistä sisäistä vahvistumista. K ehittämisohjelmissa esiintyy yhä painokkaammin sana 'empowerment' eli valtautuminen. (V iite 3). Tarvitaan toimia, jotka vahvistavat uskoa omiin kykyihin, itseluottamusta, yhteistyökykyä ja rohkeutta tarttua uusiin mahdollisuuksiin. Tämä on sitä tärkeämpää, mitä suuremmassa syrjäytymisvaarassa inminen on. Y ksi tasa-arvon testi onkin, miten paljon voimavaroja suunnataan siihen, että jokainen voi kehittää henkisiä voimavarojaan. Jatkossa tarvitaan myös yhteisöllisiä kehitysohjelmia. 
$\mathrm{N}$ iinikään toimia tarvitaan silloin, kun inmiset tai inmisryhmät joutuvat kokemaan suuria muutoksia. Sisäistä yrittäjyyttä vahvistavien opintojen avulla on mahdollista kohdata uusi elämäntilanne, yrittää ymmärtää muutoksen syitä, arvioida omia mahdollisuuksia, etsiä vahvuudet, voimavarat ja tulevaisuuden toiveet, vahvistaa itsetuntoa ja -luottamusta sekä kehittää laajoja kompetensseja. U sein tällaista tarvitaan ennen uutta ammatillista koulutusta tai sen osana. Valtautumisen tukemisesta onkin kasvamassa vapaan sivistystyön uusi erikoistehtävä, jonka tarve kasvaa yhteiskunnan nopean muuttumisen mukana. Se kannustaa sekä menetelmälliseen kehitystyöhön että etsimään rohkeasti yhteyksiä toisaalta työelämään ja toisaalta erilaisiin sosiaalisesti painottuneisiin toimintoihin.

\section{Tietoyhteiskunnan perustaidot}

Elinikäinen oppiminen edellyttää sellaista oppimisen perustaa, jonka varassa ihminen oppii uutta osana jokapäiväistä elämää. 0 ppimisella tarkoitetaan tässä koko elämän iän jatkuvaa prosessia, jossa inminen yksin tai yhdessä toisten kanssa eri tavoin hankkimaansa tietoa prosessoiden tuottaa uutta osaamista, joka ilmenee uusien taitojen kehittymisenä, ymmärryksen laajenemisena, uutena tapana tulkita asioita tai ilmiöitä ja uutena tapana suhtautua niihin. (V iite 4). Oppimaan oppimisen kyky - ei yksin sanan toistavassa vaan ymmärtävässä, omaperäisesti uutta luovassa ja uutta osaamista tuottavassa merkityksessä - on niin ihmisen kuin hänen yhteisöjensäkin yksi tärkeimmistä ominaisuuksista pyörteisesti muuttuvassa myöhäisteollisessa yhteiskunnassa. Ja vastaavasti oppimisen estyminen on suora tie syrjäytymiseen.

Elinikäisen oppimisen komitea korosti tiedollisen oppimisen ohella esteettisen, eettisen ja sosiaalisen alueen kehittämistä ja toisaalta määritteli tietoyhteiskunnan perustaidot laajasti (s. 1,47 ). K yse ei todellakaan ole vain kyvystä käsitellä tietoteknisiä koneita ja laitteita, vaan vahvasta oppimisen perustasta, jonka osia ovat oppimaan oppiminen, tiedon hankinta- ja hallintakyvyt, kommunikaatiotaidot, yhteistyö- taidot ja kulttuuriset taidot. Tietoyhteiskunnan perustaidot ovat enemmän valmiuksia kuin erityisiä oppimääriä. Tietoyhteiskunnan perustaidoista koostuva uusi yleissivistys on tärkeä osa aikuiskasvatuksen ja erityisesti yleissivistykseen vanhastaan erikoistuneen vapaan sivistystyön ajankohtaista työlistaa. A ika alkaa olla kypsä sille, että tietoyhteiskunnan perustaidot ja niiden jatkuva päivittäminen kirjoitetaan väljä-muotoisen tutkinnon perusteiksi. Tätä varten tulee kehittää vapaalle sivistystyölle ominaisia työmenetelmiä.

\section{KANSALAISTOIMINTA OPPIMISYMPÄRISTÖNÄ}

Jos persoonallisuus on vapaan sivistystyön yksi tunnus, on yhteisöllisyys toinen. Etenkin tanskalaiset kansanvalistajat puhuvat sektoreista kolmannen, kansalaisyhteiskunnan puolesta sivistystyön omimpana toimintakenttänä. Ensimmäiseen sektoriin kuuluu julkinen valta ja sen virkamiestoiminnot. Toisena toimii markkinapohjainen yritystoiminta. K olmannen sektorin ydintä on julkisen keskustelun ohella vapaaehtoinen toiminta kansalaisjärjestö issä ja muissa yhteisöissä. (viite 5). Y ksin yhdistystoiminnan määrä onkin tavattoman runsas suurista lähes puolivaltiollisista, usein sosiaalisesti painottuneista järjestöistä poliittisiin järjestöihin, etujärjestöihin, uskonnollisiin järjestöihin, neuvonnan, kasvatuksen ja koulutuksen järjestöihin, kulttuurijärjestöihin, urheilujärjestöihin, nuorisojärjestöihin, eläkeläisjärjestöihin, vammaisjärjestöihin, mitä moninaisimpiin harrastejärjestöihin, lähes loputtomiin.

Sektoreiden välillä joudutaan käymään rajaa. Esimerkiksi kirkossa on julkisyhteisön piirteitä, mutta hengellinen elämä on järjestynyt pääosin vapaaehtoiseksi seuratoiminnaksi. U rheilu on kolmatta sektoria, mutta moni urheiluseura alkaa muistuttaa liikeyritystä. Valtio on ottanut virkavastuulleen tehtäviä, jotka aiemmin hoidettiin kansalaisyhteiskunnassa. A jankohtainen kiistakysymys on, miten paljon ja millä tavoin tätä tulisi purkaa. Useimmiten kolmas sek- 
tori on esillä uutena työllistäiänä. $K$ ansalaistoiminnan perimmäistä merkitystä on kuitenkin haettava muualta.

Valtion, kansalaisyhteiskunnan ja markkinoiden välillä näyttää vallitsevan kiinnostava yhteys. 6. M issä kansalaisyhteiskunta on vahva, siellä myös valtio palveluineen toimii hyvin ja talouselämä menestyy. Mitä heikompi kansalaisyhteiskunta on, sitä huonommin toimivat myös valtio ja talous. Ja mikä pahinta, heikon kansalaisyhteiskunnan rinnakkaisilmiöitä ovat rikollisuus, korruptio ja turvattomuus. Vapaaehtoisessa kansalaistoiminnassa näyttää syntyvän jotakin sellaista, joka on kokonaisuudelle elintärkeää mutta jonka sisällön tunnemme huonosti. Pohjoismaisessa keskustelussa on viitattu siihen, että kansalaistoiminta on ikäänkuin kitti, joka liittää yhteiskunnan toiminnat yhteen. Mutta mitä tämä kitti on ja miten sitä voi saada aikaan? Tähän kysymykseen tuo sosiaalisen pääoman teoria kiinnostavan selityksen.

\section{Sosiaalinen pääoma}

Robert D. Putnamin (1993) uraauurtava tutkimus koskee I taliaa, jolle suuret sisäiset kehityserot ovat tunnusomaisia. Maan pohjoinen osa on vauras, myös hallinnoltaan hyvin toimiva ja verkottuvaan tietoyhteiskuntaan ilmeisen hyvin sopeutuva Euroopan alue. Vastaavasti eteläosa on köyhä kehitysmaa, jonka talous taantuu suurista avustuksista huolimatta, hallinto ei toimi ja alue on antanut jopa nimen eräälle vastaaviin oloihin syntyvälle rikollisuuden lajille. Putnamin tutkimuksen mukaan etelä- ja pohjoisosan perustava ero liittyy kansalaisyhteiskunnan toimintaan. Pohjoisessa inmisten välisellä horisontaalisella yhteistyöllä - esimerkkeinään kuorot, urheiluseurat ja naapurusten keskinäinen apu - on 1000-vuotinen historia. E telässä se puuttuu; kansanperinnekin ohjaa ihmisiä pitämään huolen vain omista asioistaan. "Jos naapurin talo palaa, ala kantaa vettä omaan taloosi."

Sosiaalisen pääoman ydin on ihmisten välinen luottamus ja tietysti luottamuksenarvoisuus. Sosiaalista tai luottamuspääomaa syntyy siinä kansalaisyhteiskunnan monimuotoisessa horisontaalisessa yhteistoiminnassa, jossa inmiset tapaavat toisiaan, oppivat ymmärtämään toisiaan, oppivat tietämään, miten paljon ja missä asioissa he voivat luottaa toisiinsa, ja jossa syntyy vastavuoroisuutta ja keskinäistä solidaarisuutta. Y hteistyö on pääsääntöisesti edullisempaa kuin ei-yhteistyö ja ratkaisevan tärkeä se on jälkiteollisessa muuntuvien yhteistyöverkostojen yhteiskunnassa. $\mathrm{N}$ ykyhetken altruismi on pitkän ajan egoismia. Putnam ajattelee myös, että sosiaalinen pääoma (social capital) ikäänkuin käyttää henkistä tai osaamispääomaa (human capital) ja vasta tämä yhdistelmä tuottaa taloudellista pääomaa. Tämäkin on kiinnostavaa. N s. opinnollisuus on pitkään liitetty tiedolliseen oppimiseen. Perimmiltään yhteistyökin on oppimalla hankittavaa osaamista.

$\mathrm{K}$ ansalaistoiminnan opinnollisuuteen tulisi kuulua itsestäänselvänä osana myös sosiaalisen pääoman oppiminen. Yhteisöllinen korostus nousee muutoinkin keskustelun esityslistalle useissa yhteyksissä. Ehkä yllättävääkin on, miten voimakkaasti taloudellisen yhteistyön järjestö OECD painottaa oppimistavoitteina yhteisöllistä elämää, sosiaalista koheesiota ja demokratian toimivuutta. $K$ ansalaistoiminta on kuin yhteiskuntaa koossapitävä loimisto. Ilmeistä on, että harrastus-, vapaaehtois- ja kansalaistoimin-ta luo välttämättömän pohjan niin hyvälle elämälle kuin yhteiskunnan toimivuudelle ja talouden kehitykselle. Tältä kannalta myös liikunnan ja urheilun oppilaitokset voi hyvin mielin toivottaa tervetulleeksi vapaan sivistystyön perheeseen ja saman lain piiriin.

Vapaalla sivistystyöllä on annettavaa kaikille kolmelle sektorille. Silti sen ydinmerkitys liittyy kansalaisyhteiskuntaan ja kolmanteen sektoriin, jota se - kuten Pentti Y rjölä (1998) toteaa - itsekin on. Se voi tukea yhdistystoimintaa, jonka keskeisin työmuotokin useimmiten on jokin nonformaalin oppimisen muoto, seminaareista keskusteluryhmiin. Vapaan sivistystyön pohjoismaisittain leimallisin työmuoto, opintokerho tai -piiri, on jo sekä yhteistoiminnallisen oppimisen muoto että sosiaalista pääomaa kehittävä yhteisö. 


\section{Järjestötyön kriisi}

Järjestöelämälle ei juuri nyt kuulu hyvää. O sallistuvan väen määrä vähenee. Toiminta on harvojen aktiivien varassa ja järjestöbyrokratia tuntuu usein raskaalta velvollisuudelta. Tämä herättää suuren joukon kysymyksiä? O nko kansalaisyhteiskunta kuihtumassa pois? 0 vatko opintokerhot ja -piirit muuta kuin kalpea jäänne? Väheneekö sosiaalinen pääoma? Entä, jos niin käy? O nko kyseessä väistämätön kehityskulku vai jotakin, mikä tulisi herättää toimintaan? Tekeekö televisio ja uusi viestintäteknologia kansalaistoiminnan tarpeettomaksi?

IImeistä on, että sosiaalinen pääoma on myös Suomessa useiden teollisten maiden tapaan heikentymässä ja että sen tulisi johtaa toimiin. Järjestöihin ei tietysti voi ketään pakottaa; ajatuskin on mahdoton toiminnassa, joka perustuu vapaaehtoisuuteen. K ysymykseksi jää, miten inmisten yhteistyön muotoja ja sisältöjä tulisi kehittää niin, että se kartuttaisi sosiaalista pääomaa koko yhteiskunnan tarpeisiin.

A rkkipiispa John Vikström (1993) on viitannut tärkeään näkökohtaan sanoessaan, että eräs vaihe maamme järjestöelämässä on auttamattomasti tullut tiensä päähän. $K$ ansanliikkeiden pohjalle rakentuneet järjestöt lähtivät liikkeelle alhaalta, inmisten tarpeista, unelmista, näyistä ja pyrkimyksistä. K un järjestö kasvaa suureksi, kasvusuunta muuttuu päinvastaiseksi. Järjestöjen toimistoissa sihteerit ja työryhmät alkavat laatia kampanjasuunnitelmia ja strategioita, joilla aktivoidaan passivoitunutta kenttäväkeä. K enttä on yleensä lähtenyt huonosti liikkeelle. Toimistoissa turhautuneisuus kasvaa.

Vikströmin mukaan järjestö-Suomen tragiikan syy on ilmeinen. I hmisen tarpeista lähtenyt järjestö alkaa saada omia tarpeita, joiden toteuttamisessa tarvitaan inmisiä. I hmiset kokevat, että kampanjoissa on kysymys järjestön, ei inmisen tarpeista. Se ei innosta eikä onnistu. Jokainen järjestö kohtaa sen kysymyksen, miten perustason järjestötoiminta alkaisi työskennellä ihmisten kokemien asioiden hyväksi, ei järjestön päättämien asioiden hyväksi? Järjes- töjen on puun tavoin kasvettava alhaalta ylös. Ilman ihmisten aidoista tarpeista lähtevää perustason toimintaa ei yksikään järjestö menesty, oli sen ylätaso, talous, strategia, tiedotus tai mikä muu tahansa asia kuinka hyvässä kunnossa tahansa.

\section{Uusia yhteisömuotoja}

Moniin yhteistyötarkoituksiin rekisteröity yhdistys on tarpeettoman raskas. Nopeasti yleistyvä yhteistyön muoto on verkosto, jossa siihen halukkaat ihmiset osallistuvat väljämuotoiseen yhteistoimintaan niin kauan kuin se heidän näkökulmastaan pysyy kiinnostavana ja hyödyllisenä. Y leistyvä yhteistyön muoto on niin ikään hanke tai projekti, jolla on täsmällinen tarkoitus, alku ja loppu. Yhteistyötä voi tehdä myös monella muulla tavoin; kätevä ja byrokratialtaan ohut muoto on perinteinen pohjoismainen yhdessä oppimisen ja toimimisen tapa, opintokerho. Tärkeintä on, että sosiaalista pääomaa syntyy.

Mahdollinen tulevaisuudenkuva on, että rekisteröityjä yhdistyksiä on nykyistä vähemmän ja niissä on vähemmän jäseniä. Perusjärjestöt toimivat kuitenkin organisatorisina tukikohtina, joiden sisällä, välillä ja ympärillä on monimuotoinen verkostojen, hankkeiden sekä opinto- ja toimintaryhmien floora. K asvokkaista kohtaamista täydennetään tieto- ja viestintätekniikan keinoin. Saattaa myös syntyä uusia viestintätekniikan avulla toimivia yhteisöjä. Tämä ei vähennä, vaan pikemminkin korostaa järjestöjen ja järjestöosaamisen merkitystä. Vahvoja ja suorituskykyisiä perusjärjestöjä tarvitaan silloin, kun järjestön arvot edellyttävät pitkäjänteistä toimintaa, kun kyseessä ovat mittavat taloudelliset vastuut ja kun päätöksenteko on muutoin järjestettävä täsmällisellä tavalla.

K ansalaisyhteiskunta on keskeinen oppimisympäristö niin sosiaalisen pääoman kuin monien persoonallisuuden kehitykselle tärkeiden valmiuksien kannalta. Samalla se järjestöjen 


\section{ARाIKसाT}

monimuotoisuuden vuoksi sisältää laajan skaaIan asioita. Vapaan sivistystyön oppilaitosten haasteena on löytää uudestaan tärkeäksi tuleva tehtävänsä kansalaisjärjestöjen yhteistyökumppaneina ja oppimiskeskuksina. Tässä tarvitaan joustavia ja yhteydenpitoon tietotekniikkaa käyttäviä järjestötoiminnan ja järjestöissä oppimisen muotoja.

\section{KANSANVALTAISTEN ARVOJEN VAHVISTAMINEN}

K ansansivistyksellä, kansanliikkeillä, kansallisvaltiolla ja kansanvallalla on Pohjoismaissa vahva historiallinen yhteys. Demokratia perustuu oletukselle valistuneesta kansalaisesta, joka ymmärtää yhteiskunnalliseen asemaansa vaikuttavat voimat ja joka kykenee vaikuttamaan yhteisöjensä jäsenenä. Tanskasta lähtenyt mutta kaikkiin Pohjoismaihin levinnyt grundtvigilaisittain 'kansainen' kansansivistys oli kansan itsekasvatusta, jonka avulla tavalliset inmiset kehittivät modernin valtion kansalaisina tarvitsemiaan valmiuksia. Tuloksena oli pohjoismainen hyvinvointivaltio, joka kykeni ennen näkemättömästi sekä kehittämään vaurautta että turvaamaan tasa-arvoista elämää.

Suuret ismit tulkkeinaan omat sanomalehdet ja sittemmin poliittisen kamppailun kohteena olleet sähköiset viestimet antoivat lähes koko 1900-Iuvun ajan ihmisen yhteiskunnalliseen asemaan perustuvan todellisuustulkinnan, kansanliikkeet toiminta- ja vaikutuskanavan ja paikallishallinnon ohella kansallisvaltio toimintapuitteet. $\mathrm{N}$ yt kaikki nämä tekijät ovat perusluontoisesti muuttuneet. Y hteiskunnallinen kansansivistys on kuihtunut lähes olemattomiin. Suuret ismit ovat hajonneet; oman aseman arvioiminen on käynyt vaikeaksi keskellä jälkiteollisen yhteiskunnan yhä uusia yllätyksiä tuovaa muutosta. Kansanliikkeet antavat sijaa inmisen yksilöllistymiselle. $\mathrm{K}$ ansallisvaltio on muuttunut ongelmalliseksi aikana, jota toisaalta leimaa kasvava kansojen keski-näisriippuvuus ja toisaalta globaalistuminen. Individualisoitumista, globaalistumista sekä uutta tieto- ja viestintätekniikkaa onkin pidetty tärkeimpinä syinä sille, että kysymys demokratiasta on ajateltava uudelleen. (Viite 7).

O ngelmat näkyvät myös käytännössä. Muutoksen yhteiskunnassa päätöksenteko törmää nopeita uudelleenarvioita vaativiin ongelmiin, joihin vaikuttaa uusi globaali keskinäisriippuvuus. Johtajien on pakko reagoida ongelmiin nopeasti; aikaa pitkiin ohjelmallisiin käsittelyihin ja puoIueiden sisäisiin päätöksentekoprosesseihin ei ole. Puolue-elimet kokoontuvat päättämään jo päätettyjä asioita. K ansalaiset ja jopa puolueiden jäsenet kokevat, etteivät he voi vaikuttaa asioihin ja turhautuvat. Todellinen päätöksenteko tuntuu karkaavan kansalaisten ulottumattomiin. Usko politiikkaan ja poliitikkoihin heikkenee, puolueiden jäsenmäärät pienenevät ja vaaleihin osallistumisprosentit laskevat. V iestintä tunkeutuu syvälle politiikan saloihin; silti on oma kysymyksensä, miten hyvin journalismi kykenee kaupallistumisen paineessa välittämään päätöksentekijöiden ja kansalaisten aitoa dialogia.

$K$ ansalaisten on yhä vaikeampi tehdä sitä, mitä $E U: n$ valkoinen kirja työllisyydestä nimitti "kyvyksi arvioida oma asemansa". Tuloksena on yhteiskunnallinen vieraantuminen, joka eriarvoisuuden samanaikaisesti kasvaessa purkautuu yksinkertaisia totuuksia esittäviin ääriliikkeisiin. O n viisasta myöntää, että demokratia on kriisissä eikä helppoja ratkaisuja ole näköpiirissä. On itse asiassa hämmästyttävää, miten vähän keskustelua kriisi Pohjoismaissakin herättää. Tanskassa on käynnistetty kansansivistyksen, aikuiskasvatuksen ja demokratian suhdetta selvittävä tutkimusohjelma, Ruotsissa tehdään laajaa valtaselvitystä ja joitakin yksittäisiä demokratiakasvatushankkeita on käynnissä, esimerkiksi MSL-opintokeskuksen Vaikuttaja 2000 -ohjelma. M utta valtaosin demokratiakasvatuksen kenttä on autio ja tyhjä. Ehkä vielä kärsitään 70-luvun ylipolitisoituneen ajan kohmeloa ilman että uuden luomiseen uskallettaisiin panostaa.

\section{Alustavia lähtökohtia}

Vapaan sivistystyön kannalta kansanvalta- 
kasvatus on 2000-Iuvun alun suuri haaste. E i ehkä vielä ole mahdollista nähdä tulevan tehtävän kokonaisuutta, esimerkiksi sitä, miten kansainvälistyminen ja globaalistuminen tai tieto- ja viestintätekniikka uhkineen ja mahdollisuuksineen lopulta kansanvaltaan vaikuttavat. Mutta joitakin demokraattisia arvoja vahvistavia sivistystyön tehtäviä on mahdollista esittää siten, että pidetään lähtökohtana demokratian ydinkysymyksiä.

Perustava lähtökohta on tässäkin kansalaisyhteiskunta ja sosiaalinen pääoma, erityisesti toinen toisensa ymmärtäminen ja siitä kasvava solidaarisuus. Viestintä tosin opettaa omalla passiivisella tavallaan ymmärtämään erilaisia ihmisiä ja elämänpiirejä. M utta sen lisäksi tarvitaan uutta käytännön yhteisöllisyyttä, joka tekee tilaa inmisten yksilöllisyydelle ja kokee erilaisuuden rikkautena. I hmisten aito kohtaaminen ja keskustelu on nähtävä arvokkaana tavoitteena. Elävä demokratia syntyy perustason yhteisöllisyydestä, joista osa jatkossa toiminee tieto - ja viestintätekniikan mahdollistamana. Demokratiaa tarkastellaan kansallisvaltion ohella painotetummin paikallisena ja lähiyhteisökysymyksenä. - Lokaalin lisäksi kysymykseksi nousee globaali demokratia ja sen edellyttämä globaali kansalaisyhteiskunta.

Toinen kysymys liittyy inmisen perustavaan tarpeeseen arvioida oma asemansa, siihen vaikuttavat voimat ja omat mahdollisuutensa yhteiskunnassa. Tämän antaneet ismit ja ideologiat korvautuvat pienemmillä maailmanselityksillä ja visioilla. Futurologian merkitys korostuu; Eduskuntakin on perustanut oman tulevaisuusvaliokuntansa. Perustavat yhteiskuntaa tulkitsevat ajatukset syntyvät toistaiseksi anglosaksisissa arvopohjaisissa policy studies laitoksissa. Pohjoismaat ja ehkä Eurooppa laajemminkin ovat pudonneet tästä kehityksestä; yhteiskunnallinen keskustelu on lähinnä kommentaareja amerikkalaisiin visioihin. Y hteiskunnallisen keskustelun virikkeeksi tarvittaisiin hyvin ajateltuja suomalaisia ja pohjoismaisia tulkintoja yhteiskunnallisen kehityksen luonteesta ja siitä, miten inmisten mieliä vaivaavat ongelmat olisi mahdollista rat- kaista. V apaan sivistystyön instituutiot olivat luonteva pohja toimintapoliittisen tutkimuksen käynnistämiseen, mitä tavoitetta Elinikäisen oppimisen komiteakin esitti. $\mathrm{N}$ iiden etuna ovat myös valmiit kanavat viedä keskustelua järjestöihin ja ruohonjuurille.

K olmanneksi olisi käynnistettävä kokeileva työ uuden yhteiskunnallisen kasvatuksen kehittämiseksi, myös niin että se käyttää tieto- ja viestintätekniikan uusia mahdollisuuksia. Työ kuuluu myös Pohjoismaiden ministerineuvoston kansansivistyksen ja aikuiskasvatuksen toimintaohjelmaan, jota suunnittelee oma demokratiatyöryhmä. Se kannustaa myös vapaata sivistystyötä alan kokeiluun ja kehittämiseen.

\section{Sivistystyön merkitys}

H armonisoituvan ja globaalistuvan ajan merkkejä ei tarvitse pitkään lukea sen arvion tekemiseksi, että pohjoismaisen valtion tehtäväkuva entisestään supistuu. Kansakunnan henkinen pääoma on kuitenkin niin tärkeä asia, että opetusministeriön voi ennustaa selviytyvän keskimääräistä paremmin julkisessa tulonjakokamppailussa. Varat tuskin lisääntyvät. Silti tulee nostaa päätöksentekijöiden pohdittavaksi kysymys, onko vapaan sivistystyön suhteellinen osuus nyt lähellekään oikea.

A htaasti nähtyyn ammatilliseen ja usein tekniseen tietoon painottuvan koulutuksen rajat ovat jo tulleet vastaan, myös työelämän ja sen edellyttämien laajojen kompetenssien kannalta katsottuna. Tarvitsisimme vuosisadan vaihteen tapaan uuden sivistysherätyksen, joka tunnistaa myös henkisen ja sosiaalisen ihmisen. $\mathrm{K}$ iinnostavaa on, että Ruotsi on lisäämässä pitkän supistamiskauden jälkeen sivistystyön rahoitusta, minkä taustalla on kannustaviin tuloksiin päätynyt valtakunnallinen arviointi (esim. Andersson ym, 1996).

Riittävän laaja-alaisena nähtävä (1) henkinen kasvu, valtautuminen ja oppimisen perustan vahvistaminen, osanaan aikuisväestön tietoyhteiskunnan perustaidot on vapaan sivistystyön persoonallisuuden kehityksen perinnettä jatka- 


\section{ARाIKस्ता}

va luonteva tehtävä. Jos moduloitu tutkinto antaa sille selkeämmät kasvot, mahdollisuuteen pitäisi tarttua. Tehtävässä painottuu tasa-arvonäkökulma yleensä ja myös kansanopistojen työssä ns. toisen mahdollisuuden näkökulmasta. Laajakantoinen tehtävä on (2) monimuotoisen kansalaisyhteiskunnan vahvistaminen, ei yksin siksi että se työllistää tai siksi, että se voi osin korvata nyt virkatyönä tehtäviä asioita, vaan siksi että vapaaehtoinen yhteistoiminta on koko yhteiskunnalle tärkeän sosiaalisen pääoman lähde. Kolmantena kärkenä on (3) kansanvallan vahvistaminen, minkä yhtenä tavoitteena on kyky arvioida oma asemansa keskellä pyörteisesti muuttuvaa nykymaailmaa. Pedagogisen kehittämisen kärkeen palaavat tänä tiimityön ja yhteistoiminnallisen oppimisen aikana opintokerhoperinteelle rakentuvat yhdessä oppimisen muodot.

\section{Viitteet}

1 Monet sivistystyöntekijät hankkivat omatoimisesti syvällisen näkemyksen vapaasta sivistystyöstä ja sen traditiosta, missä alan vilkkaat pohjoismaiset kosketukset auttavat. A laan perehdyttämistä ei Suomessa ole kuitenkaan erikseen järjestetty. U sein sivistystyötä tehdään muilla aloilla saadun pätevöitymisen varassa ja niiden mukaisin työtavoin. M yös vapaata sivistystyötä pohtiva julkaisutoiminta on vähäistä, mikä heikentää omaleimaisen sivistystyön kehitystä. - Koululakien uudistusta pohjustanut ns. N ummisen komitea ehdotti erityistä lakia vapaatavoitteisista opinnoista, jonka osa vapaa sivistystyö olisi ollut. Tämä koettiin alalla olemassaoloa uhkaavaksi vaaraksi.

2 Sivistymisen prosessin yhtä keskeistä piirrettä kuvaa Gustavssonin (1996, 19) hermeneuttisesta kehästä johtama käsitys:

"Kunskap och lärande är på det sättet en relation mellan det vardagligt bekanta, och det nya, okändä och främmande. D etta är också bildningstankens betydelse och mening. I sin vidaste klassiska form är bildning att betrakta som en rörelse, i vilken människan bryter upp från det vardagliga, ger sig ut i det okända, för att sedan föra tillbaka nya erfahrenheter till sig själv. D enna bildningens djupast liggande tanke ... kan uttryckas i otaliga variationer och ges en mängd olika innebörder ...".

M yyttitasolla vertaus tuhlaajapojasta on tämän yksi ilmaus.

3 Tätä painotti myös EGLEI-verkoston (E uropean $G$ roup for Local E mployment Initiatives) puheenjohtaja $\mathrm{K}$ atherine LeRoi Förbundet Nordisk Vuxenupplysningin seminaarissa Uppsalassa marraskuussa 1997. Riittävä panostus valtautumisen tukemiseen on eurooppalaisen kokemuksen mukaan työllistämishankkeiden onnistumisen edellytys. $K$ äytännön kokeiluja on ainakin Työväen Sivistysliiton ja Maaseudun Sivistysliiton ohjelmassa. Jatkossa tarvittaneen myös community deve lopment -toiminnan suomalaisia versioita.

4 Oppimisen määritelmä perustuu Eero 4 Pantzarin (1997) tiivistelmään, jonka hän laati kansainvälisen keskustelun pohjalta Elinikäisen oppimisen komitealle. O len lisännyt siihen sosiaalisen, yhdessä oppimisen näkökulman. Määritelmän etu on sen prosessipainotuksen ohella oppimisen ja osaamisen yhteyden osoittaminen. Samalla määritelmä sopii hyvin vapaaseen sivistystyöhön ja ottaa huomioon sen perinteiset korostukset eli osanottajien ohjaaman kokemusoppimisen ja asioiden merkityksen pohtimisen uusista näkökulmista.

5 K orsgaard (1997a) todistelee kiinnostavasti, miten käsitteillä kansa (vrt. kansansivistys) ja kansalaisyhteiskunta on eroistaan huolimatta runsaasti yhteisiä piirteitä. K irjansa Kampen om lyset referaatissa hän ilmaisee sen näin:

"To push it to extremes one can say that the concept of civil society was developed by British liberals whereas the 'folkelige' (popular) society was developed by German nationalists." M olemmat tarkoittivat autoritaariin valtioon syntynyttä vapauden aluetta. K ansa levisi tässä merkityksessä yhdessä Bildung-ajatuksen kanssa myös Pohjoismaihin. N ykytulkinnan mukaan kansalaisyhteiskunta koostuu intiimistä alueesta, vapaaehtoisen yhdistystoiminnan alueesta, sosiaalisista liikkeistä ja julkisesta viestinnästä.

\section{AIKUISKASVATUS 3/98}


Sille on ominaista oma- ja vapaaehtoisuus (G ustavsson 1996, 195 -).

6 Vapaaehtoisessa yhteistoiminnassa harrastustoimintaa myöten syntyy ihmisten välisiä horisontaalisia yhteyksiä, joiden heijastusvaikutus on merkittävä. Putnam (1993, 171) korostaa yhteistyössä syntyvän luottamuksen merkitystä: "Social trust in complex modern settings can arise from two related sources norms of reciprocity and networks of civic engagement." K orsgaard (1997b, 24) tiivistää vaikutuksen sanomalla, että "in the very end the prerequiste for both market and the state is non-economic ties og confidense and solidarity". Fukuyama (1995) tarkastelee periaatteessa samaa ilmiötä maailmanlaajuisesti. H jerppe $(1998,26)$ sanoo, että sosiaalisen pääoman yhteiskunnallisen vaikutuksen empiirisessä verifioinnissa on otettu ensi askeleet. $\mathrm{N}$ äitä hän itsekin ottaa mainitussa artikkelissa.

7 A rvion taustana on pohjoismaista demokratiahanketta suunnittelevan ryhmän keskustelu. Hanke kuuluu Pohjoismaisen kansansivistystyön ja aikuiskasvatuksen toimintasuunnitelmaan vuosille 1997 - 2000 ja avataan K ööpenhaminassa 3.-4.9.1998 pidettävällä konferenssilla. Suomi ottanee kansalaisyhteiskunnan ja kansanvallan kysymykset painotetusti esille myös omalla $\mathrm{EU}$ :n puheenjohtajakaudelIaan.

\section{Kirjallisutta}

ANDERSSON, Eva - Laginder, Ann-M arie - Larsson, Staffan - Sundgren, Gunnar (1996). Cirkelsamhället. Studieirklarnas betydlser för individ och lokalsanmälle Delbetänkande av Utredningen för statlig utvärdering av folkbildningen. SOU 1996:47.

FUK UYAMA, Francis (1995). Trust. The Soial Virtues and the Creation of Prosperity. Free Press.

G UST AVSSO N, Bernt (1996). Bildhing i vår tid. $0 \mathrm{~m}$ bildningens möligheer och villkor $\mathrm{i}$ de moderna samhället. Vahlström \& Widstrand.

HJERPPE, Reino (1998). Sosiaalinen pääoma taloudellisena ilmiönä. K irjassa K ajanoja, Jouko -
Simpura, Jussi 1998. Sosiaalinen pääoma. VATTjulkaisuja 24.

K ORSGAARD, O ve (1997a). Kampen om lyset. Dansk Voksenoplysning gennem 500 år. Gyldendahl.

K O RSG AARD, O ve (1997b). Internationalization and G lobalization. Esitelmä UNESCO n $\mathrm{Ham}$ purin konferenssissa. Julkaistu lehden A dult education and development numerossa 49/ 1997. Institut fur Internationale Z usammenarbeit des D eutschen Volkshochschul-Verbandes e.V.

KUISMA, Juha - N iemelä, Seppo (toim.) 1983. Santeri Alkio. Ituja. K irjayhtymä.

LONGWORTH, H. and Davies, W.K (1996). Lifeong learning $\mathrm{N}$ ew vision, new implications, new roles for people, orgasations, nations and communities in the 21st century. Kogan Page. London.

NIE M ELÄ, Seppo (1993). Suomen endot A tena.

N IE ME LÄ, Seppo (1998). E linikäinen oppiminen ja osaamisyhteiskunnan haasteet. Artikkeli kirjassa Arkipäivän oppiminen, A ikuiskasvatuksen 39. vuosikirja. $\mathrm{K}$ ansanvalistusseura ja Aikuiskasvatuksen Tutkimusseura.

Oppimisen ilo (1997). K ansallinen elinikäisen oppimisen strategia. Komiteanmietintö 1997:14.

Pohjoismaisen kansansivistystyön ja aikuiskoulutuksen toimintasuunnitelma 1997-2000. Pohjoismaiden ministerineuvosto.

PUT N A M, Robert D. (1994). Making Demoracy Work - Civic Traditions in Modern Italy. Princeton University Press. Princeton N .J.

SAV O LA, Marita (1997). H aastattelu Kansanopistolehdessä 3/ 1997.

T U O M IST O, Jukka - Pantzar, E ero (1997). Elinikäinen oppiminen kansallisena ja kansainvälisenä työn ja koulutuksen kehittämisstrategiana. K irjassa Näkökulmia dinikäiseen oppimiseen. Elinikäisen oppimisen komitean mietinnön (1997:14) liite. O petusministeriö.

YRJÖLÄ, Pentti (1998). Opintokeskusten arviointi. O petushallitus.

VIK STRÖM , John (1993). Tahtomalla vai ajautumalla - miten Suomi toimii huomenna? Alustus Allianssi ry:n seminaarissa 7.9.1993.

WILEN IUS, Reijo - O ksala, Pellervo - M ehtonen, Lauri - Juntunen, M atti (1979). Filosofian kysymyksiä. G ummerus. Jyväskylä.

Artikkeli saapui toimitukseen 20.5.1998. Se hyväksyttiin julkaistavaksi toimituskunnan kokouksessa 12.6.1998. 